\title{
Analysis of financial mechanisms in support to new pumped hydropower storage projects in Croatia
}

\author{
Goran Krajačića,*, Dražen Lončar ${ }^{\mathrm{a}}$, Neven Duić ${ }^{\mathrm{a}}$, Mladen Zeljko ${ }^{\mathrm{b}}$, Roberto Lacal Arántegui ${ }^{\mathrm{c}, 1}$, \\ Rodica Loisel $^{\mathrm{c}, 1}$, Igor Raguzin ${ }^{\mathrm{d}}$ \\ ${ }^{a}$ University of Zagreb, Faculty of Mechanical Engineering and Naval Architecture, Ivana Lučića 5, 10000 Zagreb, Croatia \\ ${ }^{\mathrm{b}}$ Energy Institute Hrvoje Požar, Savska cesta 163, pp 141, 10001 Zagreb, Croatia \\ ${ }^{\mathrm{c}}$ European Commission, DG Joint Research Centre, Institute for Energy and Transport, P.O. Box 2, 1755 ZG Petten, The Netherlands \\ ${ }^{\mathrm{d}}$ Department for Renewable Energy and Energy Efficiency, Energy Unit, Ministry of Economy, Labour and Entrepreneurship, Ulica grada Vukovara 78, 10000 Zagreb, Croatia
}

\section{H I G H L I G H T S}

- The most widespread storage in power systems is the pumped/reversible hydro storage.

- The electricity market does not adequately rewarded all services that PHS provide to the electricity system.

- The FIT-GO varies in the range of $42-265 € / \mathrm{MW}$ h for an average capacity factor of $20 \%$

\section{A R T I C L E I N F O}

\section{Article history:}

Received 5 February 2012

Received in revised form 28 June 2012

Accepted 2 July 2012

Available online xxxx

\section{Keywords:}

Pumped storage hydro

Energy storage

Integration of renewable energy sources

Financial mechanisms

Feed-in tariff

\begin{abstract}
A B S T R A C T
This paper analyses potential supporting schemes for pumped hydro storage (PHS) facilities in Croatia, which would guarantee recovery of the investment cost, with feed-in tariffs - for instance - which would guarantee payment for discharging wind-originated power as a reward for boosting the integration of renewable energy sources (RESs). The payment level acts as a floor basis for the PHS operator during the decision-making process to contract fixed payments for wind support or to act market-free on other market segments, through price arbitrage and reserve provision. The market share required for the efficient operation of a PHS facility and the levels of feed-in tariff (FIT) are set mathematically. Main findings put the level of FIT for an applied project in Croatia in the range $42-265 € / \mathrm{MW} h$ for an average load factor of $20 \%$, depending on particular local conditions, such as the level of wind power curtailment in the system, the power price for charging the storage and the number of pumps and penstocks, which could lower the capital cost. It is claimed that not all services that PHS provides to the electricity system are adequately rewarded by the electricity market, and thus there is a serious uncertainty as to how investment costs in energy storage would be recovered. Other elements, outside the market, are likely to influence the operation of PHS, such as the regulated level of a desirable rate of curtailment of RES power excess, the adequate level of energy security and the reserve margins which PHS could help to ensure.
\end{abstract}

(c) 2012 Elsevier Ltd. All rights reserved.

\section{Introduction}

The variable nature of RES - such as wind, solar and wave energy - is one of the factors limiting their higher penetration in the network. This issue was first recognized in autonomous networks, where RES penetration easily reached technical limits. Now, integrated power systems face similar problems when RES penetration exceeds certain levels. Effective use of energy storage

\footnotetext{
* Corresponding author. Tel.: +385 915658884; fax: +385 16156940.

E-mail address: goran.krajacic@fsb.hr (G. Krajačić).

1 This views expressed are purely those of the authors and may not in any circumstances be regarded as stating an official position of the European Commission.
}

could compensate for the intermittency and would increase RES penetration. Today the most widespread storage technology in power systems is pumped or reversible hydro storage, which has many advantages and can provide multiple services in transmission, distribution and generation (e.g. support to RES integration, grid upgrade and ancillary services, load shifting, etc.). Pumped hydro is the oldest and largest of all of the energy storage technologies that are commercially available, with facilities larger than 1000 MW. Globally, there are more than 100 units worldwide, with a total power of more than $130 \mathrm{GW}$ representing approximately $3 \%$ of instantaneous generating capacity [1]. In Europe there are $44 \mathrm{GW}$ of installed pumped hydro storage capacity [2] and there are plans to construct over $7 \mathrm{GW}$ of new units [3]. It is the most 
widespread energy storage system in use in the power networks and performs the primary function of load levelling and peak shaving.

Conventional pumped hydro uses two water reservoirs at different altitudes. Water is pumped from the lower reservoir to the upper reservoir during off-peak hours or when an excess of RES is available. When required, the water flow is reversed in order to generate electricity. Pumped hydro is the most practical on a large scale with discharge times ranging from several hours to a few days. Their efficiency is in the 70-85\% range. Innovations in variable-speed motors have helped these plants operate at partial capacity and have greatly reduced equipment vibrations. Pumped storage plants are characterized by long construction times and high capital expenditure. The price of new installations varies accordingly [4] from 500 to 3600 EUR/kW.

The use of traditional energy storage for increasing RES penetration has been tackled and proposed by many authors. The use of pumped hydro storage (PHS) for integration in the existing water supply system and increasing the wind penetration from $25 \%$ to $70 \%$ in the electricity supply of the Corvo island is proposed in [5] and a similar case, but which include sea desalination is given in [6]. The use of PHS for increasing wind penetration in the Lesbos island and algorithm for sizing the PHS units are described in $[7,8]$. In both papers authors showed that PHS can have excellent technical and economic performance while doubling the RES penetration. Their proposal for reducing the installation costs considers to use an existing water tank on the island as the lower reservoir of PHS. The similar studies for use of PHS in the several Greek islands are provided in $[9,10]$, where PHS is described as the optimum energy storage system for bigger islands. In [11] PHS is used in order to achieve $100 \%$ electricity supply for Portugal. A similar solution in [12] PHS is proposed for achieving a high share of wind and solar electricity supply for Croatia, increasing wind penetration and reducing of $\mathrm{CO}_{2}$ emissions in Macedonia [13] and also to reduce the wind curtailment in Europe as described in [14].

In general there are no restrictions on the size of the system, which is mostly dependent on the technology of the turbines and pumps used, which in turn are related to the available height and reservoir capacity.

The most promising option for new installations is the transformation of current reservoir hydropower plants by adding a lower or upper reservoir and by constructing pumping stations, if turbines are not suitable for reversible operations. Additionally, nohydropower dams could be converted to PHS by building a second reservoir and the necessary hydropower facilities. Another possibility is to construct of completely new pumped hydro storage plants in the most suitable locations.

In Croatia, the biggest pumped storage is the reversible 276/ -240 MW hydropower plant RHE-Velebit (generating/pumping installed capacity); there are also two smaller pumped hydro power plants CHE-Fužine 4/-4.8 MW and CHE-Lepenica 1.4/-1.25 MW. There is also the pumping station CS-Buško Blato 10.5/-10.2 MW situated in Bosnia and Herzegovina and operated by Croatian Utility Company - HEP. This study gives an overview of the Croatian potential for the suitable locations of the PHS installations, which in general could be divided into:

- Mainland - typical locations where there the current installations could be extended (e.g. building of RHE Vinodol).

- Islands - in larger islands such as Krk, where pumped storage could be combined with water irrigation service and water supply provision; the potential combination with a PV facility could be a reliable source of energy.

Integrated power systems will face problems of RES integration when its penetration exceeds certain levels. Table 1 shows EU
Table 1

EU countries with highest wind share in the gross electricity consumption in 2009 and 2010. Source: European Commission $(2010,2011)$

\begin{tabular}{lll}
\hline Country & $\begin{array}{l}\text { Wind } \\
\text { penetration } \\
2009(\%)\end{array}$ & $\begin{array}{l}\text { Wind } \\
\text { penetration } \\
2010(\%)\end{array}$ \\
\hline Denmark & 24.9 & 22 \\
Portugal & 14.6 & 17.1 \\
Spain & 13.9 & 16.6 \\
Ireland & - & 10 \\
Germany & 7.2 & 6.2 \\
\hline
\end{tabular}

countries with the highest wind share in gross electricity consumption in 2009 and 2010. Their power systems are entering the phase of large scale RES integration. Note that 2010 was considered as a low wind year in central and northern Europe.

As mentioned earlier, one of the solutions for increasing the intermittent renewable electricity (RES-E) penetration is adding energy storage to the power system. In addition to helping to increase the RES penetration, energy storage could also serve for load management, power quality management and system services (System services are all services provided by a system operator to all users connected to the system. Some users provide some system services that are ancillary to their production or consumption of energy. These system services are called "ancillary services" [15].), security of energy supply, profitable trade of energy, etc. Balancing energy flows via electricity storage can improve the capacity factors of power plants, facilitate the valuation and integration of variable electricity production, avoid power curtailment, and provide flexibility and support to electricity grid capacities through asset deferral and reduce grid congestion issues [16].

These storage benefits are of significant interest for renewable energy sources, as they offer a technological solution that maximizes the usage and benefits of renewable energy production by reducing recourse to fossil fuel-based back-up capacity and power curtailment measures, for instance. The PHS has many advantages. Current pumps/turbines have the capability to work in all possible modes of operation, under full automatic control with automatic operation of all transient states (pumping-stopping-generating) and quick change between them (1-5 min). They can be easily controlled remotely, have high start/stop frequency and the highest availability and capability to support black starts. In an integrated system, storage and pumped storage hydropower can also help reduce the challenges of integrating variable renewable resources [17].

As stated above, forecasting future needs for storage capacity is dependent on the future electricity mix, e.g. level of variable energy and the capacity of the EU grid to accommodate variable power generation. To date, there are no agreed scenarios on the requirement for additional storage capacities in Europe; however,

Table 2

Proposed PHS in Europe from [3] and projected increase 2020/2010 from the National Renewable Energy Action Plans [18].

\begin{tabular}{lcl}
\hline Country & $\begin{array}{l}\text { Proposed } \\
\text { PHS (MW) }\end{array}$ & $\begin{array}{l}\text { NREAPs-declared } \\
\text { increase by 2020 }\end{array}$ \\
\hline Switzerland (CH) & 2140 & N/A \\
Portugal (PT) & 1956 & 3266 \\
Austria (AT) & 1430 & 0 \\
Germany (DE) & 1000 & 1406 \\
Spain (ES) & 720 & 3154 \\
Slovenia (SL) & 180 & 0 \\
France & - & 2000 \\
Italy & - & 200 \\
Total & 7426 & 10,026 \\
\hline
\end{tabular}


to some extent the National Renewable Energy Action Plans (NREAPs) provide targets for increasing the PHS installed capacities. In Europe, there are many proposed PHS facilities, mostly in the countries with high wind share or with good conditions for PHS as shown in Table 2. The current hydropower system, with its regional diversity, can be further operated in a more flexible way and provide additional storage capacity to the European system as a whole.

According to [3] the estimated costs of proposed PHS in Spain and Portugal will be in the range from 486 to $2170 € / \mathrm{kW}$.

\section{Methodology}

This section applies the methodology developed in [19] to the issue of PHS in support of wind power. It helps to compute the level of support through FIT by unit of power delivered, provided that the origin of supply is wind-based. The main difference from the mechanism of FIT with Guarantee of Origin (FIT_GO) presented by Krajačić et al. in [19] for the case of the islands is that the PHS facility operates in a wide power system, which is moreover interconnected with other countries. Therefore more business oportunities are open to the PHS operator, since a deeper market is targeted and more market segments add to the wholesale market that is concerned by the FIT_GO scheme in the case of the islands.

Pumped or reversible hydro power stations - PHS will use energy from the grid for pumping water to upper reservoir, and this energy can come from all power plants in the system. The scheme with FIT_GO rewards only the PHS discharge which can guarantee the support to wind power generation or other intermittent RES. If the PHS operator chooses a conventional resource-based power to pump the water uphill, then it would be subject to the power market price. The PHS operator could find other attractive opportunities on the market, such as price arbitrage [20] and the provision of reserve power [21]. These markets are relatively deeper than the wind power surplus only, because they include the wholesale market, the secondary and tertiary reserve markets. On each reserve market, the PHS can operate on the positive and the negative reserve market for frequency regulation, given the charging and discharging mechanisms and the relatively quick response time, of 5-10 min. In this way, the supporting scheme FIT_GO would regulate the operation of PHS less and would provide the PHS investor with the trade-off between the market and regulation.

FIT_GO operates as a guaranteed payment floor for a certain number of hours in support to wind power and for fixed conditions of pre-determined rate of return. Additionally, the PHS operator can support the system by providing flexibility and participating in the margin of reserve, which ensures that the system is reliable for a high share of wind power penetration.

FIT tends to differ according to the project size, application and location as reflected in a different investment cost, and according to the wind resource intensity and wind inflow, reflected in a different capacity factor of the PHS.

FIT $_{\mathrm{PHS}_{\mathrm{WGO}}}$ represents the FIT that is paid for electricity produced by PHS which is equal to the electricity used for pumping and decreased for the total efficiency of the PHS system. Theoretically this means, that the electricity produced by PHS that will benefit from the guarantees of origin for RES-E, and not the electricity charged, as the supporting system takes losses of the PHS into account, as illustrated by the following equation:

$\mathrm{PHS}_{\mathrm{GO}}=\eta_{\mathrm{PHS}} \cdot W_{\mathrm{GO}}$

where $\mathrm{PHS}_{\mathrm{GO}}$ are guarantees of origin given to electricity produced by PHS and $W_{\mathrm{GO}}$ are guarantees of origin for wind electricity supplied from network to PHS station. $\eta_{P H S}$ is the round-trip efficiency of PHS calculated by
$\eta_{P H S}=\eta_{T} \cdot \eta_{p}$

where $\eta_{T}$ is efficiency of pumped-hydro turbines (PHT) and generators and $\eta_{p}$ is efficiency of pumping. $\eta_{P H S}$ is determined from technical documentation of proposed PHS or typical groups of similar PHS plants.

For example, for a rate of $\eta_{P H S}$ of $70 \%$ and guarantees of origin standardized to $1 \mathrm{MW} \mathrm{h}$, then for $1 \mathrm{MW}$ h of $\eta_{P H S_{W G O}}$ (RES-E coming from PHS with provable renewable origin of electricity) or $1 \mathrm{PHS}_{\mathrm{GO}}$ will need $1.4285 \mathrm{MW}$ h of $E_{\mathrm{WGO}}$ or $1.4285 W_{\mathrm{GO}}$ (RES-E coming from wind power plants with provable renewable origin of electricity). Complex accounting of GO needs a central registry, which should be located at the energy market system operator and should be supported by power system operators (TSOs or DSOs). The importance of GO is explained by [22] as it is most likely that EU-wide trade in RES-E will take the form of an exchange of guarantees of origin.

Where PHS is using only electricity with $W_{\mathrm{Go}}$ for pumping and PHS has a load factor of $\leqslant 20 \%$, FIT which will be paid for electricity with $\mathrm{PHS}_{\mathrm{GO}}$ should cover total costs of electricity production and it is calculated by formula:

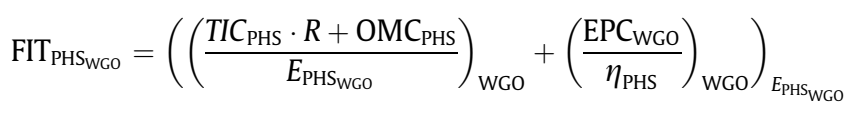

where $\mathrm{TIC}_{\mathrm{PHS}}$ is total cost of investment in PHS, $\mathrm{OMC}_{\mathrm{PHS}}$ is the yearly operation and maintenance costs of PHS, $E_{\mathrm{PHS}}$ is total delivered

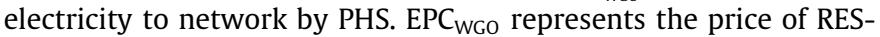
E used for pumping. Indexes $W_{\mathrm{GO}}$ only indicates to which renewable origin of electricity the terms in brackets are related.

The annuity factor $R$ is defined as:

$R=\frac{i}{1-(1+i)^{-N}}$

where $i$ is the discount rate and $N$ the payback period of the investment.

The electricity $E_{\mathrm{WGO}}$ used to charge the storage, i.e. the wind power that is otherwise curtailed has its price $\mathrm{EPC}_{\mathrm{WGO}}$ that is currently regulated through feed-in tariffs paid to the wind power operator for the contracted wind production. If the security of the system is jeopardized by high wind inflows, the wind operator is asked by TSO to curtail the wind power. The lost opportunity for wind power could not be rewarded in a market-based framework, and the price $\mathrm{EPC}_{\mathrm{WGO}}$ could vary between 0 and the market price, as the opportunity cost of the wind operator to sell this volume on the market. The business case for both wind and PHS agents would be a lower price than the market price: the wind operator has a higher reward than curtailing the power for free if he is not compensated for doing so, while the storage operator would have a lower charging fee. It is to be noted that the PHS has the freedom to choose the market or wind-originated regulated conditions. Therefore the wind operator would find it attractive to sell the excess at lower levels than the market price.

The size of hydropower and PHS plants can vary from a few hundred $\mathrm{kW}$ to hundreds of MW, and there is also big range in installation costs. Another characteristic of PHS is that they could be built by adapting the existing structures, by adding pump station and pumping penstock to existing hydropower plants which already have both reservoirs, or by adding an upper or lower reservoir, penstock, reversible turbines or turbines and pumps to the existing water reservoir as described in the case studies of the STORIES project Deliverable 2.1 [23].

Proposers of FIT for PHS systems should take into account the specific local features of the possible development of PHS and 
accordingly could, for example, propose one or more levels of FIT $_{\text {PHS }}$ (see Table 3).

When contracted, FIT $_{\mathrm{PHS}_{\mathrm{WGO}}}$ could last for a sufficiently long period, say 14 years as the current lag for FIT in Croatia, which could also represent a reasonable pay-back time for investors, considering the technical lifetime of PHS systems, which is over 40 years on average. Contracts with FIT_GO would be amenable to revision periodically in order to take into account the number of hours that the investor could operate, the market price and the value of the wind power in excess which was sold to the PHS operator. For these market variables, the revision could be set annually, but investors need a safety margin for their pay-back planning, and therefore contracting periods of 3-5 years are more suitable from the PHS investors' point of view.

\section{Potentials for pumped hydro in the Croatian energy system}

The Croatian Transmission System Operator HEP-OPS has regulated the installation of wind capacities at $360 \mathrm{MW}$, due to technical limits and the specificities of the Croatian power system. However, the prospects for installing more wind power capacities show a wide emerging wind energy market of around $6900 \mathrm{MW}$ of potential installations [24], according to the high wind potential and good site locations which the country possesses.

With plans for an increasing amount of variable electricity production in order to meet the 2020 targets, it is generally acknowledged that Europe needs to move towards a fully integrated and flexible European electricity network and market [16]. Increased spatial diversity: improved forecasting, market-based approaches, such as adjustment of the power market designs, time-of-use, demand control, real-time pricing; and grid technology options: cross-border interconnections, high-voltage direct current (HVDC) lines, power flow control technologies, smart meters, etc. are among the main enabling options for the technologies and techniques to accommodate and mitigate variability. There is a consensus within the electricity sector that electricity storage has the potential to play a complementary role alongside those options for improving the manageability, controllability, predictability and flexibility of supply and demand power flows of the European power system.

If the Croatian wind power potential is exploited accordingly, the fluctuations generated could increase, especially for a relatively correlated wind power generation along the Croatian coast. However, the operation of new PHS units could reduce this intermittency if their operation is oriented towards an active regulation and control of the Croatian power system in order to allow for more system flexibility and reliability. PHS units could easily utilize a critical excess of electricity production from wind or other intermittent sources. While the existing hydropower plants could be included in system regulation (currently only three are included in $\mathrm{P} / \mathrm{f}$ regulation) and contribute to grid support. This would enable more wind and other non-firm renewables into the system.

The part of investment costs in PHS systems could be avoided if the potential sites for their installation are located near current reservoirs of hydropower plants or near other natural and artificial

Table 3

Calculation of FIT according to capacity factor.

\begin{tabular}{ll}
\hline $\begin{array}{l}\text { Working hours at full load } \\
\text { (or energy equivalent) }\end{array}$ & FIT \\
\hline$<1750 \mathrm{~h}$ & $\mathrm{FIT}_{\mathrm{PHS}}{ }_{\mathrm{WGO}}$ \\
$1750-2750$ & $1.055 \cdot \frac{\mathrm{EPC}_{\mathrm{WGO}}}{\eta_{\mathrm{PHS}}}$ \\
$>2750$ & $1.005 \cdot \frac{\mathrm{EPC}_{\mathrm{WGO}}}{\eta_{\mathrm{PHS}}}$ \\
\hline
\end{tabular}

Table 4

Larger artificial lakes in Croatia [25].

\begin{tabular}{lcll}
\hline Lake & $\begin{array}{l}\text { Max. volume } \\
\left(10^{6} \mathrm{~m}^{3}\right)\end{array}$ & $\begin{array}{l}\text { Surface } \\
\left(\mathrm{km}^{2}\right)\end{array}$ & Basic use \\
\hline Peruća & 570.9 & 20 & $\begin{array}{l}\text { HE Peruča, HE Zakučac, HE Đale, } \\
\text { HE Kraljevac }\end{array}$ \\
Kruščica & 142.0 & 8.6 & $\begin{array}{l}\text { HE Sklope, HE Senj } \\
\text { CHE Fužine, HE Vinodol }\end{array}$ \\
Lokvarka & 35.2 & 1.79 & RHE Velebit \\
Štikada & 13.6 & 2.71 & HE Zakučac \\
Prančevići & 6.8 & 0.65 & HE Lepenica, HE Vinodol \\
Lepenica & 4.5 & 0.73 & HE Gojak \\
Sabljaci & 4.1 & 1.35 & HE Đale \\
Đale & 3.7 & 0.46 & RHE Velebit \\
Opsenica & 4.3 & 3 & HE Senj \\
Gusić & 1.6 & 0.4 & HE Vinodol \\
Bajer & 1.5 & 0.36 & Flood protection, water supply \\
Botonega & 22.1 & 2.42 & Flood protection, irrigation \\
Ričice & 35.2 & - & Flood protection, irrigation \\
Letaj & 8.3 & 0.74 &
\end{tabular}

lakes. As Croatia has few natural lakes, which are mostly in nature protected areas, potential sites could be located near artificial lakes. Table 4 shows the potential locations of PHS system near artificial lakes in Croatia.

Lakes and reservoirs shown in Table 4 are located in the southern and western parts of Croatia. There are also lakes in the northern and eastern parts, such as the lakes on the river Drava or the Lake Borovik on the River Vuka with the capacity of $8 \times 10^{6} \mathrm{~m}^{3}$, but there are no significant height differences in the land around these lakes, so they have not been taken into account. Nevertheless, if combined with irrigation flood protection and even soil drainage, some lower heads or specific locations could be utilized, and therefore integration of flows in storage assessment is important. The detailed search for available sites for PHS systems could be carried out with the use of computer programs. Authors in [26] presented a computer program that scans a terrain and identifies whether there are any feasible PHS sites on it. A brief description of the program is provided by the authors [26], including the limitations identified during the initial development. The program was used to evaluate an area of $20 \mathrm{~km} \times 40 \mathrm{~km}$ in the South West of Ireland, and the results obtained from this study are discussed in the same publication.

\subsection{FIT recommendations}

The most promising solution in the construction of PHS for Croatia would be an extension of the current storage hydropower plants. This could be done by adding lower or upper reservoirs and the construction of pumping stations where turbines and penstocks are not suited for reversible operations. A possible development of FIT for PHS in the mainland is applied to the case of hydropower plant HE Vinodol and its reservoirs (see Table 5).

The HE Vinodol is a part of complex hydrological and hydropower system consisting of several lakes (reservoirs), hydropower plants, pumping stations and penstocks (Fig. 1).

Table 5

Dimension and use of lakes/reservoirs for HE Vinodol.

\begin{tabular}{lcll}
\hline Lake & $\begin{array}{l}\text { Max. volume } \\
\left(10^{6} \mathrm{~m}^{3}\right)\end{array}$ & $\begin{array}{l}\text { Surface } \\
\left(\mathrm{km}^{2}\right)\end{array}$ & Hydropower plant \\
\hline Lepenica & 4.5 & 0.73 & HE Lepenica, HE Vinodol \\
Lokvarka & 35.2 & 1.79 & CHE Fužine, HE Vinodol \\
Bajer & 1.5 & 0.36 & HE Vinodol \\
Tribalj & 1.5 & 0.46 & $\begin{array}{l}\text { HE Vinodol, lower } \\
\text { reservoir }\end{array}$ \\
\hline
\end{tabular}




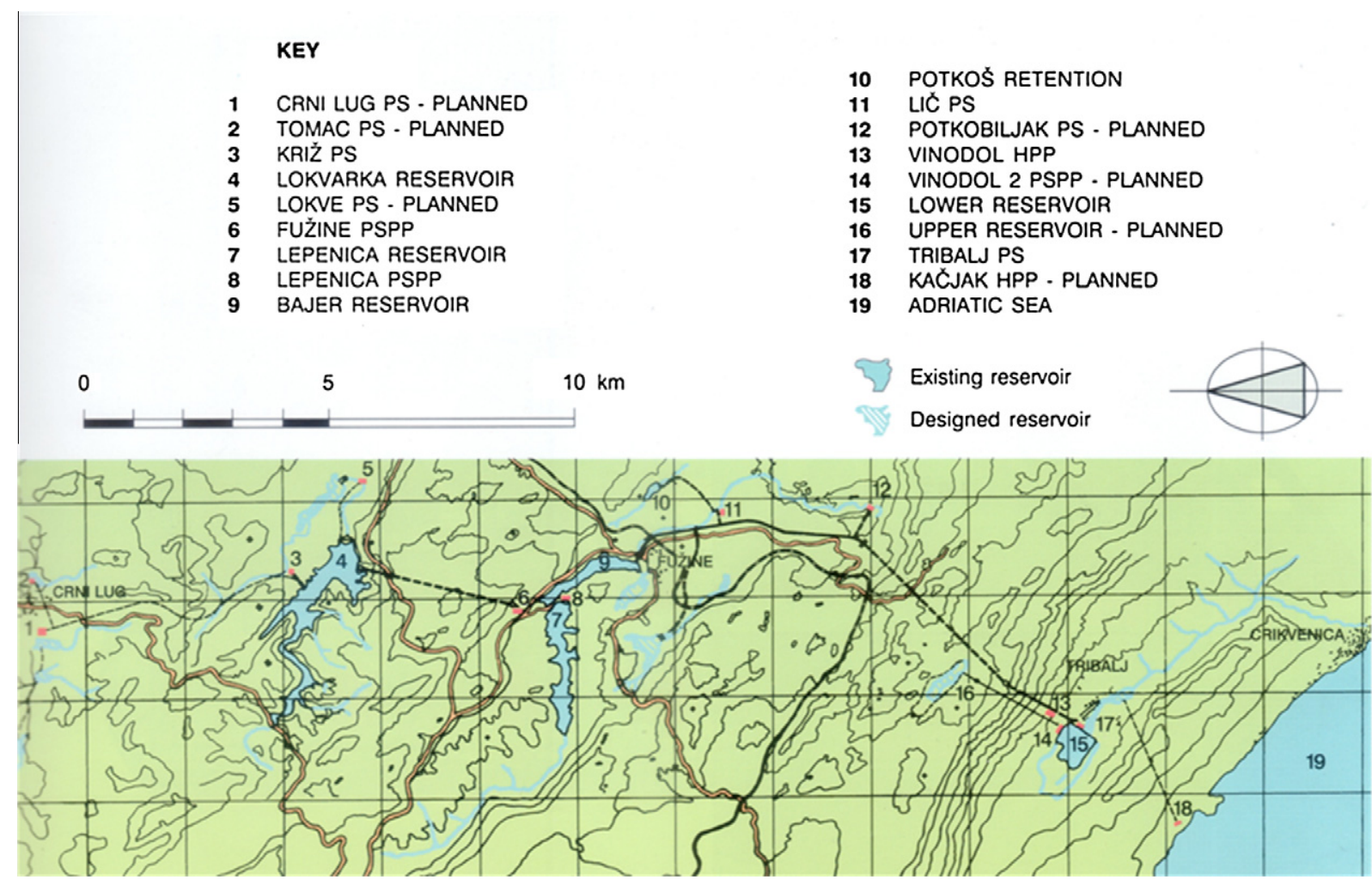

Fig. 1. HE Vinodol - description of system [27].

Table 6

Cost estimation for PHS Vinodol in EUR.

\begin{tabular}{|c|c|c|c|c|}
\hline Equipment-cost symbol & $\begin{array}{l}\text { Case (a) new pumps, penstocks } \\
\text { and reservoir }\end{array}$ & $\begin{array}{l}\text { Case (b) new pumps and } \\
\text { reservoir }\end{array}$ & $\begin{array}{l}\text { Case }(\mathrm{c}) \text { new turbines, pumps, } \\
\text { penstocks and reservoir }\end{array}$ & $\begin{array}{l}\text { Case }(d) \text { new PHS with two } \\
\text { reservoirs }\end{array}$ \\
\hline Hydro-turbine $\left(C_{\mathrm{T}}\right)$ & - & - & $17,255,570$ & $17,255,570$ \\
\hline Pumps $\left(C_{\mathrm{P}}\right)$ & $8,159,013$ & $8,159,013$ & $8,159,013$ & $8,159,013$ \\
\hline Penstock ( $\left.C_{\text {Penstock }}\right)$ & $6,205,795$ & 600,561 & $12,411,591$ & $12,411,591$ \\
\hline Reservoir $\left(C_{R}\right)$ & $21,928,976$ & $21,928,976$ & $21,928,976$ & $43,857,952$ \\
\hline Grid connection $\left(C_{\mathrm{GC}}\right)$ & $1,451,751$ & $1,227,542$ & $2,390,206$ & $3,267,365$ \\
\hline Control system $\left(C_{\mathrm{CS}}\right)$ & 580,701 & 491,017 & 956,082 & $1,306,946$ \\
\hline Transportation of equipment $\left(C_{\mathrm{T}}\right)$ & 871,051 & 736,525 & $1,434,124$ & $1,960,419$ \\
\hline Personal $\left(C_{\mathrm{P}}\right)$ & $10,888,135$ & $9,206,565$ & $17,926,545$ & $24,505,238$ \\
\hline Others $\left(C_{0}\right)$ & $2,540,565$ & $2,148,198$ & $4,182,860$ & $5,717,889$ \\
\hline Total investment & $52,625,987$ & $44,498,397$ & $86,644,967$ & $118,441,982$ \\
\hline $\begin{array}{l}\text { Yearly operation and } \\
\text { maintenance (OMC }{ }_{\mathrm{PHS}} \text { ) }\end{array}$ & $1,052,520$ & 889,968 & $1,732,899$ & $2,368,840$ \\
\hline
\end{tabular}

The water collecting area is not particularly large (about $80 \mathrm{~km}^{2}$ ), but its key benefit is that most of the upper reservoirs are located at a height above $700 \mathrm{~m}$, which gives $658 \mathrm{~m}$ of gross head of the HE Vinodol. The dimensions and use of lakes/reservoirs for HE Vinodol are presented in Table 5. The system has been in operation since 1952, and in 1985 it was expanded to include the Lepenica pumped storage hydro power plant.

The main parts of the Vinodol Hydropower System are explained in (Fig. 2): Lokvarka dam and reservoir, Fužine pump storage power plant and Bajer reservoir, Lepenica dam and reservoir, Lepenica pump storage plant, Križ pumping station, Lič pumping station, Lokvarka-Ličanka tunnel, Križ connecting tunnel, Lič pipeline, Kobljak-Razromir tunnel, penstock and powerhouse of Vinodol power plant. Total installed capacity of HE Vinodol is $94.5 \mathrm{MW}$ (3 generating sets $\times 2$ turbines $\times 15.75 \mathrm{MW}$ ) with maximum annual production achieved in the period $(1976-2006) E_{\max }=$ $197 \mathrm{GW}$ h and average yearly production $E_{\text {aver }}=139 \mathrm{GW} \mathrm{h}$.

If the volumes of all upper reservoirs are combined, the maximal potential energy stored in the upper reservoirs for HE Vinodol alone is around $70 \mathrm{GW} \mathrm{h}$. Annual capacity factors are in the range of $16.8 \%$ for an average year, while a factor of $23.8 \%$ was achieved in the year with the maximum annual production. There have been plans to build PHS Vinodol II, which will consist of a pump and turbine station (number 14), penstocks and an additional upper reservoir (number 16) as described in Figs. 1 and 2.

It is assumed for the purposes of this study that the new upper lake for PHS Vinodol will have a total volume of 5,491,235 $\mathrm{m}^{3}$, which is more than double the size of the planned upper Razromir reservoir given in [27], while the assumed height will be lower than those assumed in the same publication, i.e. somewhere 
KEY

\section{CRNI LUG PS - PLANNED}

TOMAC PS - PLANNED

KRIŽ PS

LOKVARKA RESERVOIR

LOKVE PS - PLANNED

FUŽINE PSPP

LEPENICA RESERVOIR

LEPENICA PSPP

BAJER RESERVOIR

\author{
POTKOŠ RETENTION \\ LIČ PS \\ POTKOBILJAK PS - PLANNED \\ VINODOL HPP \\ VINODOL 2 PSPP - PLANNED \\ LOWER RESERVOIR \\ UPPER RESERVOIR - PLANNED \\ TRIBALJ PS \\ KAČJAK HPP - PLANNED \\ ADRIATIC SEA
}

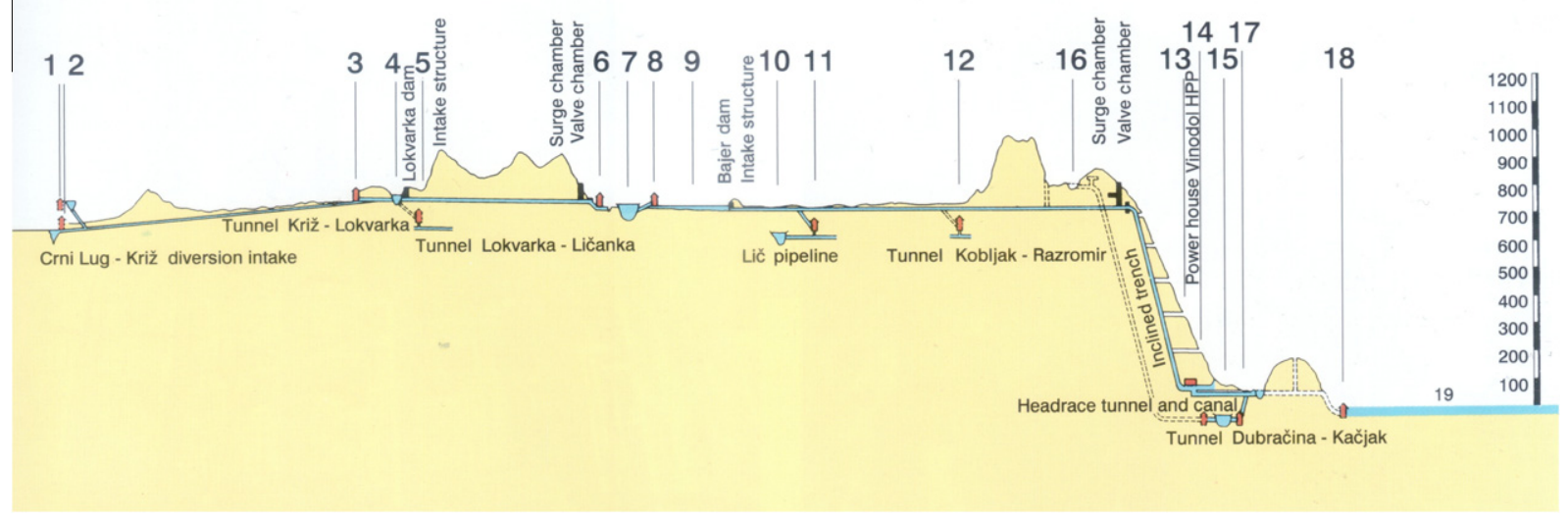

Fig. 2. HE Vinodol - schematic cross-section of existing and planned facilities [27].

between 770 and $780 \mathrm{~m}$ above sea level. The assumed roundtrip efficiency of PHS calculated by Eq. (2) is 0.7832 .

In order to present a general overview of the possibilities for PHS construction and FIT recommendations, the following calculations have been made:

(a) FIT for adding a pump station, penstock and upper reservoir to the existing hydropower plant.

(b) FIT for adding a pump station and upper reservoir while partly using old penstock of the existing hydropower plant.

(c) FIT for construction of new PHS, including pump station, new turbines, penstocks and upper or lower reservoir.

(d) FIT for construction of new PHS, including new pumps and turbines, penstocks, upper and lower reservoir.

In all calculations it is assumed that four new pumps will be installed, each with a rated power of $34 \mathrm{MW}$. This reference scenario, called Case (a), is analyzed in parallel with a scenario called Case (b) where only $300 \mathrm{~m}$ of additional penstocks result in lower investment costs than in Case (a). Alternatively, two cases - Case (c) and Case (d) - are tested where four new PHTs are installed (30 MW each), parallel penstock and additional lower reservoir respectively, with the same capacity as the upper reservoir.
The costs for all cases are estimated according to the formulae and assumptions for the PHS cost estimation explained in [19] and they are presented in Table 6 . The only difference from the recommended values in [19] are the $C_{0, \mathrm{P}}$ factor, which has been increased to 2000 due to use of the large pumps with variable speed drive, which are not so common on the market, and it is assumed that new penstocks will be constructed without insulation.

Estimation of the costs of the PHS system according to the empirical formulas given in $[19,28]$ can be used only for the first evaluation of pre-feasibility studies and grading of similar projects, as a more detailed analysis should be employed for each proposed PHS system in the same group of used technology. The disadvantage of using empirical formulas proposed for new installations of overall PHS system for calculations of different options within one particular system can be seen in Table 6 , where costs of the grid connection have been calculated differently for the units with the same size of pumps and PHTs. Similar results will be achieved only if reservoir size is varied, as the costs of grid connection, control systems, personnel, etc. are considered as a percentage of the basic equipment cost (PHTs, pumps, penstocks and reservoirs).

As no detailed calculations were made for the optimal size of PHS in Croatian conditions, a sensitivity analysis was conducted and FIT calculated for three sets of capacity factors of turbines/

Table 7

Cost of the electricity production from PHS in $€ / \mathrm{MW} \mathrm{h}$, based on 870 full load hours of turbines or energy equivalent.

\begin{tabular}{|c|c|c|c|c|c|c|c|c|c|c|c|c|}
\hline \multirow[t]{3}{*}{ Interest rate (\%) } & \multicolumn{12}{|c|}{ Payback period (years) } \\
\hline & \multicolumn{3}{|c|}{ Case (a) } & \multicolumn{3}{|c|}{ Case (b) } & \multicolumn{3}{|c|}{ Case (c) } & \multicolumn{3}{|c|}{ Case (d) } \\
\hline & 6 & 8 & 10 & 6 & 8 & 10 & 6 & 8 & 10 & 6 & 8 & 10 \\
\hline \multicolumn{13}{|c|}{ Cost of the electricity production without the cost of the wind electricity for pumping } \\
\hline 6 & 143 & 116 & 100 & 121 & 98 & 84 & 185 & 150 & 129 & 253 & 205 & 177 \\
\hline 8 & 151 & 124 & 108 & 128 & 105 & 91 & 196 & 161 & 140 & 268 & 220 & 192 \\
\hline 10 & 160 & 133 & 117 & 135 & 112 & 99 & 207 & 172 & 152 & 283 & 235 & 207 \\
\hline \multicolumn{13}{|c|}{ Cost of the electricity production with the cost of $97.5 € / M W h$ for the wind electricity for pumping } \\
\hline 6 & 267 & 240 & 224 & 245 & 222 & 209 & 310 & 275 & 254 & 378 & 330 & 301 \\
\hline 8 & 276 & 249 & 233 & 252 & 229 & 216 & 321 & 286 & 265 & 393 & 345 & 316 \\
\hline 10 & 284 & 257 & 241 & 260 & 237 & 223 & 332 & 297 & 276 & 408 & 360 & 332 \\
\hline
\end{tabular}


Table 8

Cost of the electricity production from PHS in $€ / \mathrm{MW} \mathrm{h}$, based on 1750 full load hours of turbines or energy equivalent.

\begin{tabular}{|c|c|c|c|c|c|c|c|c|c|c|c|c|}
\hline \multirow[t]{3}{*}{ Interest rate $(\%)$} & \multicolumn{12}{|c|}{ Payback period (years) } \\
\hline & \multicolumn{3}{|c|}{ Case (a) } & \multicolumn{3}{|c|}{ Case (b) } & \multicolumn{3}{|c|}{ Case (c) } & \multicolumn{3}{|c|}{ Case (d) } \\
\hline & 6 & 8 & 10 & 6 & 8 & 10 & 6 & 8 & 10 & 6 & 8 & 10 \\
\hline \multicolumn{13}{|c|}{ Cost of the electricity production without the cost of the wind electricity for pumping } \\
\hline 6 & 71 & 58 & 50 & 60 & 49 & 42 & 92 & 75 & 64 & 126 & 102 & 88 \\
\hline 8 & 75 & 62 & 54 & 64 & 52 & 45 & 98 & 80 & 70 & 133 & 109 & 95 \\
\hline 10 & 79 & 66 & 58 & 67 & 56 & 49 & 103 & 86 & 75 & 141 & 117 & 103 \\
\hline \multicolumn{13}{|c|}{ Cost of the electricity production with the cost of $97.5 € / M W h$ for the wind electricity for pumping } \\
\hline 6 & 196 & 182 & 174 & 185 & 173 & 166 & 217 & 199 & 189 & 250 & 227 & 212 \\
\hline 8 & 200 & 186 & 178 & 188 & 177 & 170 & 222 & 205 & 194 & 258 & 234 & 220 \\
\hline 10 & 204 & 191 & 183 & 192 & 180 & 174 & 228 & 210 & 200 & 265 & 241 & 228 \\
\hline
\end{tabular}

Table 9

Cost of the electricity production from PHS in $€ / \mathrm{MW} \mathrm{h}$, based on 2630 full load hours of turbines or energy equivalent.

\begin{tabular}{|c|c|c|c|c|c|c|c|c|c|c|c|c|}
\hline \multirow[t]{3}{*}{ Interest rate $(\%)$} & \multicolumn{12}{|c|}{ Payback period (years) } \\
\hline & \multicolumn{3}{|c|}{ Case (a) } & \multicolumn{3}{|c|}{ Case (b) } & \multicolumn{3}{|c|}{ Case $(\mathrm{c})$} & \multicolumn{3}{|c|}{ Case (d) } \\
\hline & 6 & 8 & 10 & 6 & 8 & 10 & 6 & 8 & 10 & 6 & 8 & 10 \\
\hline \multicolumn{13}{|c|}{ Cost of the electricity production without the cost of the wind electricity for pumping } \\
\hline 6 & 47 & 38 & 33 & 40 & 32 & 28 & 61 & 50 & 43 & 84 & 68 & 58 \\
\hline 8 & 50 & 41 & 36 & 42 & 35 & 30 & 65 & 53 & 46 & 89 & 73 & 63 \\
\hline 10 & 53 & 44 & 39 & 45 & 37 & 33 & 69 & 57 & 50 & 94 & 78 & 69 \\
\hline \multicolumn{13}{|c|}{ Cost of the electricity production with the cost of $97.5 € / M W h$ for the wind electricity for pumping } \\
\hline 6 & 172 & 163 & 157 & 164 & 157 & 152 & 186 & 174 & 167 & 208 & 192 & 183 \\
\hline 8 & 175 & 166 & 160 & 167 & 159 & 155 & 189 & 178 & 171 & 213 & 197 & 188 \\
\hline 10 & 177 & 168 & 163 & 169 & 162 & 157 & 193 & 181 & 175 & 218 & 202 & 193 \\
\hline
\end{tabular}

generators, corresponding to $10 \%, 20 \%$ and $30 \%$ full load hours (FLH) or energy equivalent.

Results for $10 \%$ are presented in Table 7 , and for $20 \%$ and $30 \%$ in Tables 8 and 9 respectively.

The PHS FIT could be designed in steps in order to reward differently the generation from different load curves of PHS. For example, the first tranche could cover a $20 \%$ load factor (1750 FLH) FIT, then another tariff between 1750 and 2750 full load hours, and a third tranche when it works more than 2750 FLH. A stepped tariff is easily calculated using the equations given in Table 3 and they are presented in Table 10. This tariff encourages the PHS operator to pump even more than the contracted hours and, as the investment is returned by $1750 \mathrm{FLH}$, the tariff thereafter only depends on the price of the wind electricity. Instead of stepped FIT, the PHS could also operate on the free market. This operation is described at the end of the sub-chapter.

If the PHS in Case (a) is used to pump water uphill when guaranties of origin for used electricity could not be ensured, for example if electricity is purchased on the spot market, in order to cover the investment and operation costs and insure desirable payback, the lowest selling price of electricity from PHS has to be calculated by adding the O\&M costs of the turbine part and the spot market price of the electricity used for pumping, divided by PHS efficiency, to the costs of the electricity production without the cost of the wind electricity for pumping stated in Tables 7-9.

Table 10

FIT according to different capacity factor for contracted 1750 full load hours.

\begin{tabular}{ll}
\hline $\begin{array}{l}\text { Working hours at full load (or energy } \\
\text { equivalent) }\end{array}$ & FIT \\
\hline$<1750 \mathrm{~h}$ & Selected FIT ${ }_{\text {PHS }}$ from \\
& Table 8 \\
$1750-2750$ & $131.3 € / \mathrm{MW} \mathrm{h}$ \\
$>2750$ & $125.1 € / \mathrm{MW} \mathrm{h}$ \\
\hline
\end{tabular}

The costs in Case (d) are equal to the costs of installing a complete new PHS system.

The formalized approach used in this study enabled an order of magnitude to be calculated for the supporting schemes of PHS contributing directly to the wind power integration in the Croatian power system. This level varies with the cost of the electricity in excess sold to the PHS operator, with the technical parameters of the PHS system to operate during one year, with the number of pumps and penstocks installed which could lower the investment cost, with the pre-determined contractual conditions such as the number of years to pay back the capital cost and the rate of return agreed by both regulator and PHS investor.

As a summary of the results presented in our calculus, when the electricity from wind excess is charged for free, the FIT_GO varies in the range of $42-141 € / \mathrm{MW} \mathrm{h}$ for an average capacity factor of $20 \%$ ( $1750 \mathrm{FLH})$. This range is wider for a lower number of operating hours ( $84-283 € / \mathrm{MW} \mathrm{h}$ for $870 \mathrm{FLH}$ ) and is narrower for higher generation rates $(28-94 € / \mathrm{MW}$ h at $2630 \mathrm{FLH})$.

When the electricity charged is at a fixed tariff, $97.5 € / \mathrm{MW} \mathrm{h}$, the level of FIT_GO naturally increases and reaches 166-265€/ $\mathrm{MWh}$ for $1750 \mathrm{FLH}, 209-408 € / \mathrm{MWh}$ for $870 \mathrm{FLH}$ and 152$218 € / \mathrm{MW}$ h at $2630 \mathrm{FLH}$.

These levels are to be analyzed by both regulator and investor when setting the profitability of a PHS project. The reasonable range for both agents is the average number of FLH of $20 \%$ yearly, which could enable the PHS operator, where it is technically possible, to improve the business prospects by operating on other market segments and diversifying the risks and the benefits. This would provide an opportunity for the PHS operator to cumulate all possible benefits it can obtain on the market and to benefit from the market price volatility which is the main business driver of the storage. From a system perspective, it could also benefit from wind power support from all the services that PHS can provide, given its technically proven characteristics, such as rapid response time, 
high seasonal storage capacity, fast switching of charging-discharging operations and an unlimited number of cycles.

Since market opportunities are hampered by reduced connection capacities in the Croatian islands, another business case applies to entire or partial remote areas. Therefore, this study analyses the level of FIT_GO for those investors who might choose island locations for their projects.

\subsection{Feed in tariffs for PHS in the islands}

In general, PHS systems are not geologically suited for Croatian islands, as most of them do not have natural or artificial lakes with potable or fresh water; moreover, lower precipitation in such schemes on the islands will require a large water collecting area which will be hard to implement on porous ground and with significant evaporation during summer months. All the populated islands of Croatia are connected to a mainland grid, so it is easy to export/import electricity and most of them have water pipelines that are also connected to the mainland in order to satisfy their water needs. PHS systems will only make sense if the islands want to become more independent from the import of resources from the mainland and if they would like to integrate PHS systems with water supply network and irrigation for agriculture.

The most interesting island for PHS systems is the Island of Cres, as it has the natural lake Vransko Jezero with a surface area of $5.745 \mathrm{~km}^{2}$ and a volume of potable water of $220 \times 10^{6} \mathrm{~m}^{3}$; it also has possibilities for the construction of an upper reservoir at promising heights of 200-400 m above sea level, plus the island of Krk with two artificial lakes, Jezero and Ponikve, and scope for reservoirs at lower levels.

Vransko Jezero on the Island of Cres is a specific protected area, so the case study for the Croatian Islands will be based on the case of the Ponikve artificial lake on the Island of Krk. The maximum volume of water in Lake Ponikve is $2.65 \times 10^{6} \mathrm{~m}^{3}$ with a water level at $+19.01 \mathrm{~m}$ above the sea level. There is a possibility to construct an upper reservoir approximately $2000 \mathrm{~m}$ from the lake at the height of approximately $200 \mathrm{~m}$ above sea level.

For the calculated case, it was assumed that an upper reservoir of $1 \times 10^{6} \mathrm{~m}^{3}$, pump and PHT station with two pumps/turbines of $5 \mathrm{MW}$ each and two penstocks would be constructed. Water management and evaporation have not been included in pre-feasibility study but they are important factors and must be assessed for each PHS system separately.

Costs for the case of PHS on the Island of Krk are estimated to be similar to costs in the case of PHS on mainland, according to [19] and they are presented in the Table 11 . Costs for the installation of penstocks are taken to be higher than on the mainland, while the efficiency of PHS is set at 0.792 as a completely new PHS is being considered. The assumed FIT for solar photovoltaic electricity $E_{\text {PVGO }}$ that will be used for pumping is $0.15 € / \mathrm{kW} \mathrm{h}$.

Table 11

Cost estimation for PHS on the Island of Krk.

\begin{tabular}{ll}
\hline Equipment - cost symbol & Cost estimation $(€)$ \\
\hline Hydro-turbine $\left(C_{\mathrm{T}}\right)$ & $2,860,157$ \\
Pumps $\left(C_{\mathrm{P}}\right)$ & $1,106,961$ \\
Penstock $\left(C_{\text {Penstock }}\right)$ & $4,112,296$ \\
Reservoir $\left(C_{\mathrm{R}}\right)$ & $6,656,551$ \\
Grid connection $\left(C_{\mathrm{GC}}\right)$ & 589,439 \\
Control system $\left(C_{\mathrm{CS}}\right)$ & 235,775 \\
Transportation of equipment $\left(C_{\mathrm{T}}\right)$ & 353,663 \\
Personal $\left(C_{\mathrm{P}}\right)$ & $4,420,790$ \\
Others $\left(C_{\mathrm{O}}\right)$ & $1,031,518$ \\
Total & $21,367,150$ \\
Operation and maintenance $\left(\mathrm{OMC}_{\mathrm{PHS}}\right)$ & 427,343 \\
\hline
\end{tabular}

Table 12

FIT for kW h of electricity from PHS on the Island of Krk ( $€ / M W h)$.

\begin{tabular}{rllll}
\hline Interest rate (\%) & \multicolumn{4}{l}{ Payback (years) } \\
\cline { 2 - 5 } & 6 & 8 & 10 & 20 \\
\hline 6 & 462 & 410 & 380 & 320 \\
8 & 478 & 426 & 396 & 338 \\
10 & 494 & 443 & 413 & 357 \\
\hline
\end{tabular}

Table 13

Cost of electricity production from PHS without price of energy from the grid (PV electricity) in the case on the Island of $\mathrm{Krk}(€ / \mathrm{MW} \mathrm{h})$.

\begin{tabular}{rllll}
\hline Interest rate (\%) & \multicolumn{4}{l}{ Payback (years) } \\
\cline { 2 - 5 } & 6 & 8 & 10 & 20 \\
\hline 6 & 273 & 221 & 190 & 131 \\
8 & 289 & 237 & 206 & 149 \\
10 & 305 & 253 & 223 & 168 \\
\hline
\end{tabular}

Table 14

FIT in the case of the Island of Krk according to capacity factor.

\begin{tabular}{ll}
\hline $\begin{array}{l}\text { Working hours at full load (or energy } \\
\text { equivalent) }\end{array}$ & FIT \\
\hline$<1750 \mathrm{~h}$ & Selected FIT $_{\mathrm{PHS}_{\mathrm{WGO}}}$ from Table \\
& 12 \\
$1750-2750$ & $199.8 € / \mathrm{MW} \mathrm{h}$ \\
$>2750$ & $190.3 € / \mathrm{MW} \mathrm{h}$ \\
\hline
\end{tabular}

FIT $_{\mathrm{PHS}_{\mathrm{WGO}}}$ or in the case of photovoltaic FIT $_{\mathrm{PHS}} \mathrm{PVGO}_{\mathrm{P}}$ for PHS in the case on the Island of Krk is calculated according to Eq. (3) and presented in Table 12, while the cost of electricity production from PHS without the price of energy is shown in Table 13. The assumed capacity factor of turbines in PHS is $20 \%$ or 1750 full load hours. FIT according to capacity factor is presented in Table 14 .

\section{Discussion}

\subsection{Implementation of the FIT}

Wind excess or curtailment, capacities of pumps and PHT are not the only factors that are relevant for the construction of a PHS system. Other important factors include the capacities of reservoirs, differences in their elevations and water availability, evaporation and the geology of the terrain. In order to optimize all important factors regarding the technical and economic aspects of the PHS system, and to determine their capacity, a detailed hourly analysis of power system needs to be made, with detailed grid data and historical time series of power loads, hydrological and meteorological data.

For a particular energy system, the limit on the load factor of turbines in PHS, which will be supported by a different level of FIT, should be optimized according to the desirable level of excess production from RES units or according to the needs of security of supply or of the energy autonomy of the system as described by Kaldellis et al. in [10].

This limit for stepped tariff design could be determined through a system optimization of the following parameters: security of energy supply or energy autonomy, reduction of RES-E curtailment, desirable RES-E targets/penetration levels, system regulation, costs and benefits of PHS installation. Stepped FITs are a tool to reduce the producer surplus and, consequently, the burden on society [29].

Including $100 \%$ of tariffs to protect against inflation is the best way to ensure stability for investors. The amount of the FIT for 
electricity produced in plants using renewable energy sources during the validity of the contract for the purchase of electricity will be adjusted annually for the retail price index, so that the FIT for the previous calendar year is multiplied by the annual retail price index for the previous calendar year, that is

$\mathrm{FIT}_{\mathrm{YPHS}}=\mathrm{FIT}_{\mathrm{YPHS}-1} \cdot \mathrm{IRP}_{\mathrm{YPHS}-1}$

where FIT $_{\mathrm{YPHS}}$ is the incentive price for the current calendar year. FIT $_{\text {YPHS-1 }}$ is the incentive price for the previous calendar year. For the first year it represents the amount of the tariff item FITYPHS referred to the methodology in Section 2. IRP YPHS-1 $_{\text {is the annual retail }}$ price index according to official data from the Central Bureau of Statistics for the previous calendar year. YPHS is the year index.

Authors in [30] describe a system in which the feed-in tariff schedule is updated each year, taking the inflation rate into consideration. The compensation is not full, however, as it amounts to only $25 \%$ of inflation. The reason stated is that less than full compensation provides an incentive to continually improve the efficiency of the subsidized unit through innovation, learning, and so on.

Where there is an extra inflow of water in the upper reservoir which enables the load factor of turbines $\geqslant 20 \%$ (or any other calculated optimal limit), FIT for electricity produced in this way should be calculated according to the formula:

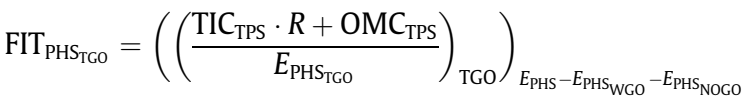

$E_{\mathrm{PHS}_{\mathrm{TGO}}}=E_{\mathrm{PHS}}-E_{\mathrm{PHS}_{\mathrm{WGO}}}-E_{\mathrm{PHS}_{\mathrm{NOGO}}}$

$E_{\mathrm{PHS}}{ }_{\mathrm{WGO}}=\eta_{\mathrm{PHS}} \cdot E_{\mathrm{WGO}}$

$E_{\mathrm{PHS}_{\mathrm{NOGO}}}=\eta_{\mathrm{PHS}} \cdot E_{\mathrm{NOGO}}$

$E_{\mathrm{PHS}_{\mathrm{TGO}}}$ is the electricity produced by the extra inflow of water, $E_{\mathrm{PHS}}{ }_{\mathrm{WGO}}$ is the electricity produced by PHS with GO (by $W_{\text {WGO }}-$ energy taken from grid with $W_{\mathrm{GO}}$ is used for pumping) and $E_{\mathrm{PHS}_{\mathrm{NOGO}}}$ electricity produced by PHS without GO (by $E_{\mathrm{NOGO}}$ - energy taken from the grid without $W_{\mathrm{GO}}$ is used for pumping). TIC $\mathrm{TPS}_{\mathrm{TPS}}$ represents total investment costs for hydro power plant (turbines, generators, penstock and eventually upper reservoir without pumping part). The FIT $_{\mathrm{PHS}_{\mathrm{T} G \mathrm{O}}}$ should cover only cost of PHS when it operates as hydro power plant, which means that $\mathrm{TIC}_{\mathrm{TPS}}$ should be determined from the ratio $\frac{E_{\mathrm{PHS}} \mathrm{TGO}_{\mathrm{TG}}}{E_{\mathrm{PHS}}}$

FIT for electricity produced by PHS, if there are no guarantees of origin for electricity used for pumping, is calculated as follows:

$\mathrm{FIT}_{\mathrm{PHS}_{\mathrm{NOGO}}}=0$

This means that the operator of PHS is buying electricity and selling back $E_{\mathrm{PHS}_{\mathrm{NOGO}}}$ according to market prices. This mode of PHS operation will depend on the market organization and contracting procedures. If the market is not developed, this mode of operation could be allowed only if there are no scheduled requests for pumping of RES-E from the system operator, in order to avoid rejection of RES-E excess production. Otherwise, if the market acts freely, the wind operator could bid a price to the PHS that is lower than the market price and there is no need for extra regulation, as the regulation applies by itself.

If, for some reason, TSO or DSO asks the PHS operator to pump and fill upper storage, and if they cannot provide GO for electricity for pumping, the PHS owner should receive compensation for this operation. This availability for operation could be rewarded according to rules for balancing energy, such as those prescribed in network operation codes, where a payment for capacity could also be provided or an extra payment for the energy delivered.
A possible organization of the market for invoicing, payments, insuring GO and fees for FIT is explained in [19].

\subsection{PHS and EU energy legislation}

In the study on energy storage technologies submitted to the European Parliament [31], it is stated that energy storage technologies could contribute to European energy security if they could enable the increased penetration of intermittent RES. The means by which the European electricity market is regulated and the nature of the electricity markets are key policy issues determining the extent to which energy storage could contribute effectively to energy security and reduction of emissions. In the EU there is strong political, public and economic support for renewable energy technologies. Political support is reflected through the European Energy Policy and mostly through directives such as Directive 2001/77/EC for support of generation of electricity from renewable energy sources, which was superseded by Directive 2009/28/EC on the promotion of the use of energy from renewable sources; the RES and Climate Change package 20-20-20 and many other recommendations and reports. While Directive 2001/77/EC had set a target to meet $12 \%$ of electricity production from RES, Directive 2009/28/EC sets a RES target for 2020 of $20 \%$ of the gross final energy consumption.

According to Article 5 of Directive 2009/28/EC of the European Parliament and of the Council of 23 April 2009 on the promotion of the use of energy from renewable sources and amending and subsequently repealing Directives 2001/77/EC and 2003/30/EC, production of electricity in pumped storage units from water that has previously been pumped uphill is not treated as renewable electricity, since the power used while pumping does not necessarily originate from wind or solar power. In order to confine the discharge with PHS within the RES accounts, a guarantee of resource origin would be useful in order to be recognized in statistics accepted within RES targets. As previously mentioned, the system that can ensure tracking of origin is explained in [19].

According the RES Directive, electricity that is used by the pumped storage is counted as part of the gross final consumption of energy, which means that - if used - it will increase the amount of energy from renewable sources that should be met in year 2020 . On the other hand, all of the electricity that is produced by wind power plants (taken directly from the grid or used to pump water uphill or for any other dump load) will be counted in the gross final consumption of electricity from renewable energy sources.

The framework for FIT suggests formalizing the share of the RES power generation which is used to pump the water in order to assess, at country level, the ways in which the pumped hydro could increase RES-E penetration and its contribution to the national RES targets. Increasing the RES-E penetration by use of pumped hydro is possible due to the big difference between gross electricity consumption and RES production. When this difference is small, the benefits of pumped storage in terms of increasing the RES share under the current Directive are not taken into consideration and may be very small or negligible. However, the Directive does stress the need to take into account the holistic cost of generating electricity and also the fact that the main policy objectives are not just economic but also environmental and health related.

Financial compensation ought to be paid if renewable energy generators are curtailed, where curtailment is necessary for safety and reliability reasons. Strong support to storage technologies has been provided in the preamble of the Directive 2009/28/EC, where it is stated that there is a need to support the integration of energy from renewable sources into the transmission and distribution grid and the use of energy storage systems for the integration of intermittent production of energy from renewable sources. The same support is also reflected in Article 16 of the Directive dealing 
with the access to and operation of the grids: "Member States shall take the appropriate steps to develop transmission and distribution grid infrastructure, intelligent networks, storage facilities and the electricity system, in order to allow the secure operation of the electricity system as it accommodates the further development of electricity production from renewable energy sources, including interconnection between Member States and between Member States and third countries. Member States shall also take appropriate steps to accelerate authorization procedures for grid infrastructure and to coordinate approval of grid infrastructure with administrative and planning procedures".

Taking into account the discussion in previous paragraphs concerning how storage is dealt with in the Directive and theoretical calculations in [11], it can be proved that Member States could be hampered in terms of achieving their RES 2020 targets. As a hypothetical example for 2020 in some country, real achieved share of RES in the gross final energy consumption could be $20 \%$, although according the rules of Directive 2009/28/EC and the treatment of stored RES, it will be admitted only up to $18 \%$ or similar. This conclusion also has a number of other implications, as the European Union's policy is to promote use of storage technologies in order to increase the integration of renewable sources as explained in previous subchapters, while at the same time it has created a serious barrier in its own Directive 2009/28/EC [32].

\section{Conclusion}

The European electricity market remains fragmented. The differences in regulation and market operation and differing conditions on markets create an unstable framework for energy storage. In particular there are few incentives and little real support for energy storage to be introduced in many European electricity markets that do not yet enjoy full liberalization and transparency.

This study analyzed the conditions under which a PHS project could be integrated in the supporting mechanism developed in Croatia for the integration of intermittent RES power generation. At EU level, this regulatory framework enshrined in Directive $2009 / 28 / E C$, provides the conditions for the integration of renewables, and Member States decide on the level of financial support for those generators that enables them to achieve the target. Since PHS is pursuing the same goal, namely to increase RES generation by avoiding the curtailment of power by storing the excess or by providing ancillary services, one possible way of financing PHS would be through a tariff system involving regulation, combined with market financial mechanisms (public-private partnerships, tax incentives, etc.).

A clear regulatory framework which guarantees the payment of the capital cost and a reasonable rate of return would make the business environment for investors clearer, both for storage and RES operators. The link with the market through the prices for electricity and reserve powers, plus a periodic revision, would enable the risk to be split between consumers and investors, and would also create the conditions for a competitive market operation.

FIT support has limited funds to pay to all RES producers. In order to spend those funds on the most promising technologies and measures that will increase wind share in Croatia, all alternatives except the construction of new PHS should be considered, optimized and evaluated on the basis of objective criteria (improving wind forecasting, grid reinforcement, increase of regulation capacity, etc.)

The price paid for energy from PHS could be calculated by the energy regulation authority on the basis of real or actual costs in order to reduce uncertainty as regards the calculation of the feed-in tariff for PHS.
PHS in the islands could be part of a hybrid system integrated with desalination and water supply network. In such a case, the burden of investment could be also passed onto the water consumers.

\section{Acknowledgments}

The authors would like to thank the reviewers for their valuable comments that improved the paper. They also thank the European Commission for the support given to the Intelligent Energy Europe project STORIES, the Ministry of Science, Education and Sport of the Republic of Croatia, which is supporting the project Smart Energy Storage for Sustainable Development of Energy Systems and the Croatian Ministry of Economy, Labour and Entrepreneurship, Energy Institute Hrvoje Požar and Centre for Transfer of Technology for the support for the development of feed-in tariffs for PHS systems that led to this paper being written.

\section{References}

[1] ALSTOM. Hydro pumped storage power plant. Brochure. Levallois-Perret Cedex/Paris: ALSTOM; 2010. PWER/BPROB/HDPSTR09/eng/HYD/12.09/FR/ 7033.

[2] Vennemann P, Gruber KH, Haaheim JU, Kunsch A, Sistenich HP, Thoni HR Pumped storage plants - status and perspectives. VGB PowerTech 2011:4:32-8.

[3] Deane JP, O'Gallachoir BP, McKeogh EJ. Techno-economic review of existing and new pumped hydro energy storage plant. Renew Sustain Energy Rev 2010;14:1293-302.

[4] European Commission. TECHNOLOGY MAP of the European strategic energy technology plan (SET-Plan). Luxembourg: Publications Office of the European Union; 2011 Joint Research Centre - European Commission. ISBN 978-92-7921630-5 2011.

[5] Duić N, Krajačić G, Carvalho MG. Renew Islands methodology for sustainable energy and resource planning for islands. Renew Sustain Energy Rev 2008;12(4):1032-62

[6] Segurado R, Krajačić G, Duić N, Alves L. Increasing the penetration of renewable energy resources in S. Vicente, Cape Verde. Appl Energy 2011;88:466-72.

[7] Kaldellis JK, Kapsali M, Kavadias KA. Energy balance analysis of wind-based pumped hydro storage systems in remote island electrical networks. Appl Energy 2010;87:2427-37.

[8] Kapsali M, Kaldellis JK. Combining hydro and variable wind power generation by means of pumped-storage under economically viable terms. Appl Energy 2010;87:3475-85.

[9] Caralis G, Rados K, Zervos A. On the market of wind with hydro-pumped storage systems in autonomous Greek islands. Renew Sustain Energy Rev 2010;14:2221-6.

[10] Kaldellis JK, Zafirakis D, Kavadias K. Techno-economic comparison of energy storage systems for island autonomous electrical networks. Renew Sustain Energy Rev 2009;13(2):378-92.

[11] Krajačić G, Duić N, Carvalho MG. How to achieve a 100\% RES electricity supply for Portugal? Appl Energy 2011;88:508-17.

[12] Krajačić G, Duić N, Zmijarević Z, Vad Mathiesen B, Anić Vučinić A, Carvalho MDG. Planning for a $100 \%$ independent energy system based on smart energy storage for integration of renewables and $\mathrm{CO}_{2}$ emissions reduction. Appl Therm Eng 2011;31:2073-83.

[13] Ćosić B, Markovska N, Krajačić G, Taseska V, Duić N. Environmental and economic aspects of higher RES penetration into Macedonian power system. Appl Therm Eng 2012;43:158-62.

[14] Loisel R, Mercier A, Gatzen C, Elms N, Petric H. Valuation framework for large scale electricity storage in a case with wind curtailment. Energy Policy 2010;38:7323-37.

[15] EURELECTRIC. Ancillary services - unbundling electricity products - an emerging market. Report. Brussels: Union of the Electricity Industry EURELECTRIC; 2004 Union of the Electricity Industry - EURELECTRIC. 2003150-0007.

[16] European Commission. 2009 Technology map of the European strategic energy technology plan (SET-Plan). Plan. Luxembourg, EU: Publications Office of the European Union; 2009 Joint Research Centre - European Commission. ISBN 978-92-79-14587-2

[17] Branche E. Black-out 2006 and role of hydro on a pan-European scale [Internet]; 2011 <http://www.eurelectric.org/download/download.aspx? UserID=26196\&DocumentFileID=70438> [cited 09.11.11]

[18] Beurskens LWM, Hekkenberg M, Vethman P. Energy Centre of the Netherlands: Renewable Energy Projections as Published in the Nationa Renewable Energy Action Plans of the European Member States, update 28.11.11. [Internet]; 2011. <http://www.ecn.nl/docs/library/report/2010/ e10069.pdf $>$ [cited 07.11.11]. 
[19] Krajačić G, Duić N, Tsikalakis A, Zoulias M, Caralis G, Panteri E, et al. Feed-in tariffs for promotion of energy storage technologies. Energy Policy 2011;39:1410-25

[20] Connolly D, Lund H, Finn P, Mathiesen BV, Leahy M. Practical operation strategies for pumped hydroelectric energy storage (PHES) utilising electricity price arbitrage. Energy Policy 2011;39(7):4189-96.

[21] Steffen B. Prospects for pumped-hydro storage in Germany. Energy Policy 2012;45:420-9.

[22] Ragwitz M, Hed A, Resch G, Haas R, Faber T, Huber C, et al. Assessment and optimisation of renewable energy support schemes in the European electricity market. Final Report of the project OPTRES. Brussels: Supported by the European Commission; 2007.

[23] Tsikalakis AG, Hatziargyriou ND, Caralis G, Zervos A, Zoulias E, Stamatakis E et al. Market applications for energy storage methods and RES. STORIES project; 2009.

[24] Capuder T, Pandžić H, Kuzle I, Škrlec D. Specifics of integration of wind power plants into the Croatian transmission network. Appl Energy; 2012. http:// dx.doi.org/10.1016/j.apenergy.2012.05.002.

[25] Gereš D. Water resources and irrigation systems in coastal and karstic regions of Croatia. In: Ožanić N, Benac Č, DeLuka Tibljaš A, Vrkljan I, editors. Manual for the hydro-irrigation: aspects of water management in development of irrigation in the coastal and inland Croatian karst. Rijeka, Croatia: Faculty of Civil Engineering, University of Rijeka; 2007. p. 23-68 [in Croatian].

[26] Connolly D, MacLaughlin S, Leahy M. Development of a computer program to locate potential sites for pumped hydroelectric energy storage. Energy 2010;32:375-81.

[27] Sever Z, Franković B, Pavlin Ž, Stanković V. Hydroelectric power plants in Croatia. Zagreb: Hrvataska elektroprivreda d.d.; 2000.

[28] Caralis G, Zervos A. Analysis of the combined use of wind and pumped storage systems in autonomous Greek islands. IET Renew Power Gen 2007;1(1):49-60.

[29] Huber C, et al. Green-X: Deriving optimal promotion strategies for increasing the share of RES-E in a dynamic European electricity market. Final report of the EU-funded project GREEN-X. Austria: Vienna University of Technology; 2004.

[30] Danchev S, Maniatis G, Tsakanikas A. Returns on investment in electricity producing photovoltaic systems under de-escalating feed-in tariffs: the case of Greece. Renew Sustain Energy Rev 2010;14:500-5.

[31] Naish C, McCubbin I, Edberg O, Harfoot M. Outlook of energy storage technologies. Study. Brussels: European Parliament; 2008 European Parliament. IP/A/ITRE/FWC/2006-087/Lot 4/C1/SC2.

[32] Krajačić G. The role of energy storage in planning of a $100 \%$ renewable energy systems. PhD Thesis. Zagreb: University of Zagreb - Faculty of Mechanical Engineering and Naval Architecture; 2012. 